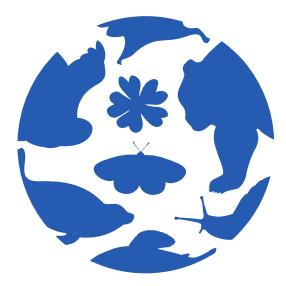

SUOMEN

LUONTO

PANEELI

\title{
LUONNON MONIMUOTOISUUS JA VIHREÄ ELVYTYS
}

Lassi Ahlvik, Christoffer Boström, Jaana Bäck, Irina Herzon, Jukka Jokimäki, Kirsi Pauliina Kallio, Tarmo Ketola, Liisa Kulmala, Aleksi Lehikoinen, Tiina M.

Nieminen, Elina Oksanen, Minna Pappila, Juha Pöyry, Heli Saarikoski, Aki Sinkkonen, llari Sääksjärvi ja Janne S. Kotiaho

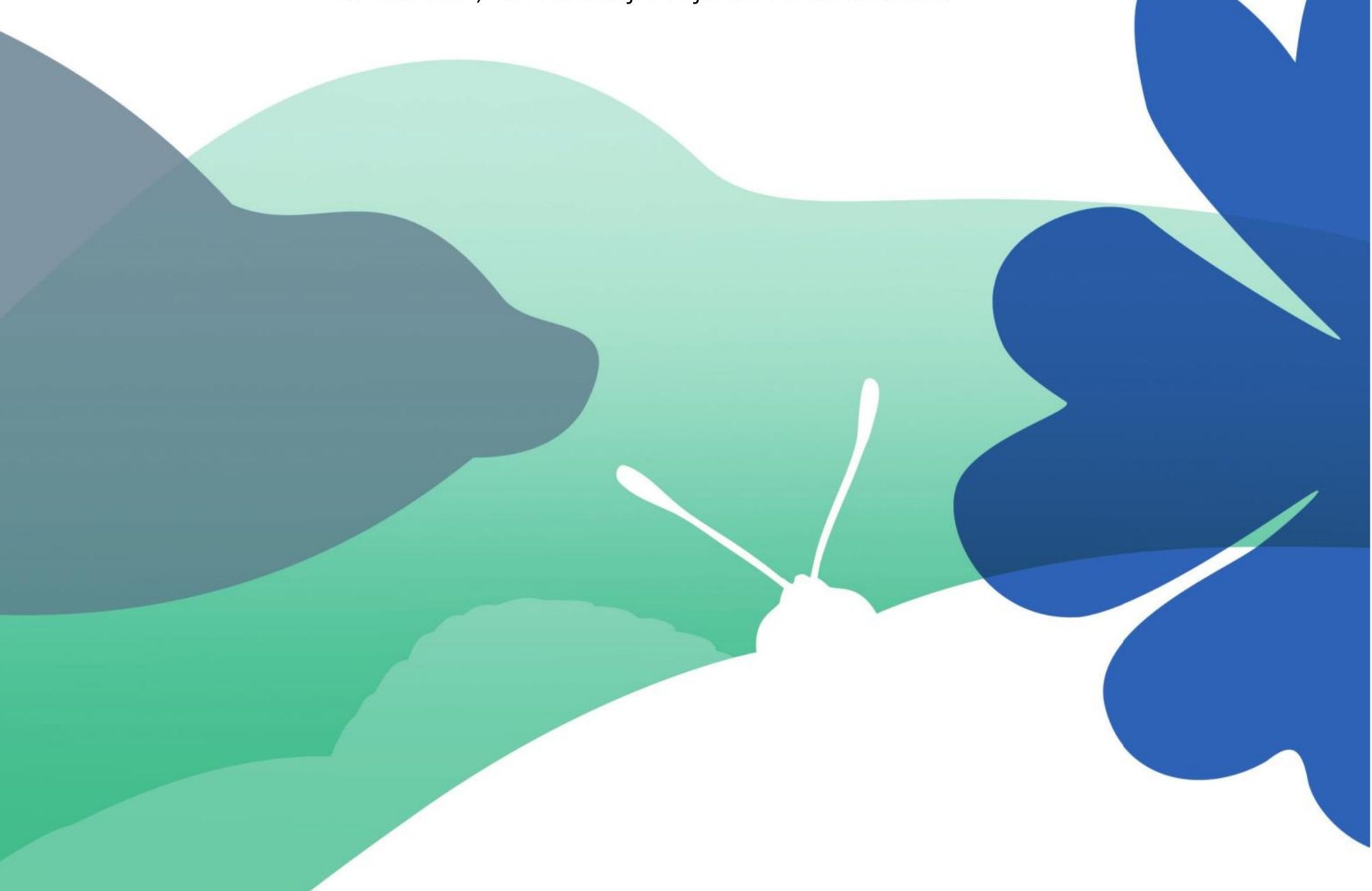




\section{JOHDANTO}

Suomi on toistaiseksi selvinnyt koronaviruksen (COVID-19) aiheuttamasta kriisistä taloudellisesti verrokkimaita paremmin, mutta työllisyystilanne on silti heikentynyt ympäri maata ja talouden ennustetaan supistuvan noin 4,7 prosenttia vuonna 20201,2. Negatiivisten talousvaikutusten minimoimiseksi hallitus on suuntaamassa EU:n elpymisvälineestä varoja käytettäväksi toimiin, jotka samanaikaisesti auttavat ratkaisemaan aikamme kahta merkittävää kriisiä: ilmastonmuutosta ja luontokatoa. Kyse on aidosti vakavista kriiseistä. Esimerkiksi Maailman talousfoorumi on listannut luonnon ekosysteemien romahduksen ja ilmastonmuutoksen torjunnan epäonnistumisen sekä vaikutuksiltaan että todennäköisyydeltään viiden vakavimman ihmiskuntaa uhkaavan riskin joukkoon ${ }^{3}$. Elämämme on täysin riippuvainen ekosysteemien ja lajien olemassaolosta ja niiden toiminnasta 4 .

Suomen Luontopaneeli katsoo, että elvytystoimien pitää kokonaisuudessaan auttaa yhteiskuntaamme selviämään koronan aiheuttamasta talouden supistumisesta niin, että elvytystoimet samalla aikaansaavat siirtymän kohti hiilineutraaliutta ja luonnon kokonaisheikentymättömyyttä. Tässä kannanotossa Luontopaneeli arvioi ympäristöministeriön kestävän elvytyksen työryhmän ${ }^{5}$ ja Suomen ilmastopaneelin ${ }^{6}$ esittämien sekä muutamien muiden elvytystoimien luontovaikutuksia ja antaa suosituksia elvytystoimien mahdollisten haitallisten luontovaikutusten välttämiseksi.

Kuvaan 1 (sivulla 3) on koottu Luontopaneelin näkemys eri toimenpiteiden luonnon monimuotoisuus- ja elvytysvaikutuksista. Lähtökohta ja tavoite on luonnon kokonaisheikentymättömyys (engl. "no net loss of the integrity of ecosystems"). Suomen maaekosysteemien, sisävesien ja meriluonnon tilan heikkeneminen tulee pysäyttää seuraavien vuosikymmenten kuluessa ${ }^{7}$. Osa toimenpiteistä vaikuttaa luonnon monimuotoisuuteen suoraan, esimerkiksi maankäytön kautta, ja osa epäsuorasti ilmastonmuutoksen (ks. tietolaatikko s. 7 ), ilmansaasteiden (s. 10) tai rehevöittävien ravinteiden (s. 11) kautta.

Moni taloutta elvyttävä ja hiilineutraaliutta edistävä toimi voi aiheuttaa luontohaittaa. Kyse ei ole vastakkainasettelusta vaan siitä, että aidosti hyvät toimet voivat olla elvyttävyys-, ilmasto- tai luontovaikutuksiltaan ristiriitaisia. Tällaiset toimet tulisi suunnitella niin, että ne ovat yhdenmukaisia luonnon kokonaisheikentymättömyystavoitteen kanssa. Väistämättömät haitat tulee hyvittää luonnolle ekologisilla kompensaatioilla (ks. s. 4). Tämän kannanoton tarkoitus on tunnistaa ristiriitoja ja löytää keinoja lieventää niitä. Jokaisen toimenpiteen vaikutukset on arvioitu ja niiden osalta on esitetty ehdotukset siitä, kuinka mahdollisia haitallisia luontovaikutuksia voidaan pienentää. 


\section{Elvytysvaikutus}

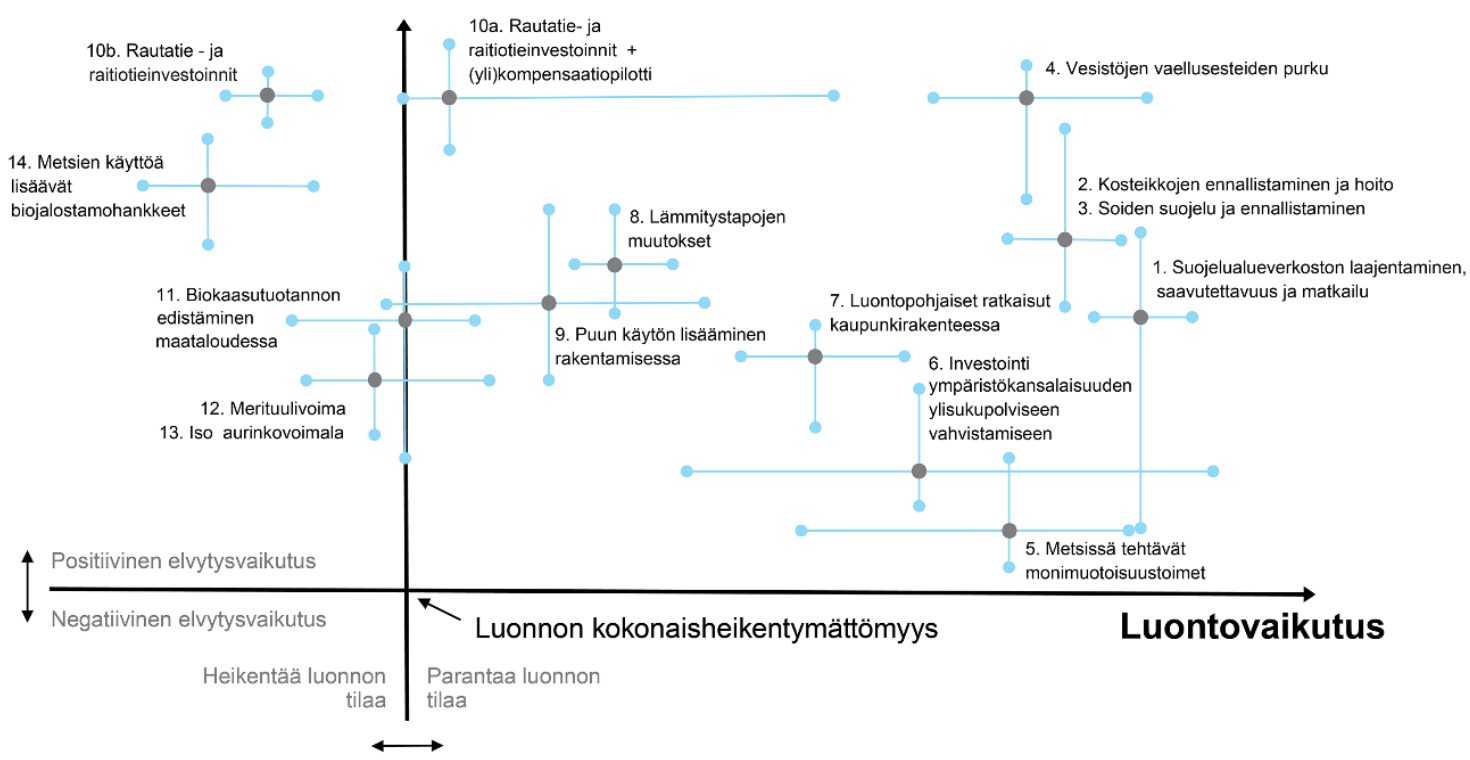

Kuva 1. Eri toimenpiteiden elvytys- ja luontovaikutukset. Mitä ylempänä kuvassa toimenpide sijaitsee, sitä suurempi on sen työllisyysvaikutus ja mitä kauempana oikealla toimenpide sijaitsee, sitä positiivisempi on sen vaikutus luonnon monimuotoisuuteen. Kuvaajan oikeassa ylänurkassa ovat toimenpiteet, joilla on parhaat työllisyys- ja luontovaikutukset ja alhaalla vasemmalla vastaavasti heikoimmat. Toimenpiteet on numeroitu parhaimman luontovaikutuksen mukaisessa järjestyksessä. Viikset kuvaavat vaikutusten arvioituja vaihteluvälejä. Toimenpiteen sijoittuminen vaihteluvälin ääripäiden välille riippuu toimenpiteen toteutustavasta. Tarkemmat kuvaukset toimenpiteiden vaikutuksista ja niihin liittyvistä suosituksista on esitetty sivuilla 5-12. 


\section{Luonnon kokonaisheikentymättömyys ja ekologinen kompensaatio}

Luonnon monimuotoisuuden heikkenemisen eli luontokadon pysäyttäminen on YK:n biodiversiteettisopimuksen ${ }^{8}$, EU: $\mathrm{n}^{7}$ ja Suomen biodiversiteettistrategioiden ${ }^{9}$ sekä pääministeri Sanna Marinin hallitusohjelman ${ }^{10}$ tavoite. Tavoitteen saavuttaminen edellyttää sitoutumista luonnon kokonaisheikentymättömyyteen, joka tarkoittaa, että ekosysteemien tilaa ei heikennetä nykyisestä. Yhteiskuntien kehitystä ei kuitenkaan voi lopettaa, mikä tarkoittaa, että kaikkia luontohaittoja ei ole mahdollista välttää.

Väistämättömien luontohaittojen hyvittäminen on välttämätöntä, jotta luontokato saadaan pysäytettyä ja voimme päästä kohti kokonaisheikentymätöntä tai jopa paranevaa luonnon tilaa. Haittojen hyvittäminen eli ekologinen kompensaatio toteutetaan yleensä elinympäristöjä ennallistamalla ja suojelemalla. Ennallistamisen seurauksena heikentyneet ekosysteemit palautuvat kohti luonnontilaa ja palautumista voidaan käyttää haittojen hyvitykseen. Kun alue suojellaan, siihen kohdistuva ihmistoiminnasta aiheutuva käyttöpaine vähenee. Suojelutoimenpiteillä aikaansaatua ekologisen tilan paranemista voidaan niin ikään käyttää haittojen hyvitykseen.

Ekologiset haitat ovat usein nopeita, täydellisiä ja pysyviä tai pitkäkestoisia. Ennallistamisen ja suojelun kautta saavutettavat hyvitykset taas ovat osittaisia, epävarmoja ja viiveellä toteutuvia. Luonnon kokonaisheikentymättömyyden varmistamiseksi hyvitys voidaan toteuttaa haittaa suuremmalla pinta-alalla eli niin kutsuttuna ylikompensaationa.

Toimivan ekologisen kompensaatiojärjestelmän toteuttaminen vaatii huolellista suunnittelua ja noin viiteentoista kysymykseen vastaamista. Nämä kysymykset jäsentävät kompensaatiot tavoitteiden, tilan, ajan, luonnon monimuotoisuuden ja toimenpiteiden suhteen ja mahdollistavat uskottavan ekologisen kompensaation toteuttamisen ${ }^{11,12,13,14}$.

Tietotaito ekologisten kompensaatioiden käytännön toteuttamiseen on Suomessa olemassa. Ensimmäinen kattava haittojen arviointi ja hyvityslaskenta on julkaistu osana Anglo American Sakatti Mining Oy:n mahdollisen Sakatin kaivoksen ympäristövaikutusten arviointia. 


\section{ELVYTYSTOIMIEN LUONTOVAIKUTUKSET JA SUOSITUKSET LUONTOHAITTOJEN EHKÄISEMISEKSI}

\section{Suojelualueverkoston laajentaminen, saavutettavuus ja matkailu}

Luontomatkailu on merkittävä talouden sektori niin Suomessa kuin globaalisti ja sen tuoman työllisyyden ylläpito ja kehittäminen on tärkeää. Matkailun taloudelliset vaikutukset vaihtelevat alueellisesti. Lapissa luontoon perustuva matkailu on aluetaloudellisesti erittäin tärkeä ja kansainvälisten matkailijoiden osuus on huomattava. Sekä Järvi-Suomi että saaristo- ja rannikkoalueet ovat puolestaan merkittäviä erityisesti kotimaisen luontomatkailun kannalta, mutta myös kansainvälistymistoimiin on viime vuosina panostettu ${ }^{16,17}$. Kotimaanmatkailun arvostus on kasvanut vastuullisuusteemojen nousun myötä, mutta erityisesti COVID19pandemia on nostanut lähimatkailun merkitystä ja kasvattanut kansallispuistojen ja muiden suojelualueiden kävijämääriä ${ }^{18}$. Luontomatkailun kasvulla on positiivisia vaikutuksia, mutta se aiheuttaa myös esimerkiksi luonnon kulumista, roskaantumista, vieraslajien leviämistä ja lajien häirintää.

Luontomatkailun kasvu vaatii luontoalueiden kestävyyden huomioimista ja investointeja haittavaikutusten minimoimiseksi. Lisäksi alueiden lisääntyneen käytön vaikutuksia on seurattava. Jotta sekä mannermaan että mereisten kansallispuistojen ja lähivirkistysalueiden vetovoimaisuus säilyy tulevaisuudessa, tulee sekä ympäristön että palveluvarustuksen tilaan kiinnittää erityistä huomiota ${ }^{19,20}$. Keskeinen toimenpide niin pohjoisessa kuin etelässä on olemassa olevien suojelualueiden laajentamien ja kehittäminen sekä yleisen luontotietouden lisääminen.

Korjaavista toimenpiteistä keskeisimpiä ovat suosittujen kohteiden palveluvarustuksen lisääminen sekä kovan käytön myötä vaurioituneiden rakenteiden ja ympäristöjen korjaus sekä ennallistaminen. Kansallispuistojen ja lähivirkistysalueiden hoidon ja kunnostamisen resursointi voidaan turvata osana vihreää elvytystä. Samalla kuntia voidaan myös kannustaa uusien suojelu- ja virkistysalueiden suunnitteluun ja toteutukseen osana kaavoitusta. Tämä lisää kansalaisten mahdollisuuksia nauttia lähiluonnosta, vähentää tarvetta matkustaa pitkiä matkoja ja tarjoaa mielekkäitä ulkoilu- ja oppimismahdollisuuksia, joita myös päiväkodit, koulut ja yhdistykset voivat toiminnassaan hyödyntää. Luontokeskusten, luonnontieteellisten museoiden, kasvitieteellisten puutarhojen ja tiedekeskusten kehittäminen ja näyttelyiden päivittäminen on merkittävässä roolissa paikallisväestön ja matkailijoiden yleisen ympäristö- ja luontotietoisuuden lisäämisessä, elämyksellisten luontokokemusten mahdollistamisessa sekä luontosuhteen ja -yhteyden vahvistamisessa. Uusien luontomatkailutuotteiden suunnitteluun ja kehittämiseen voitaisiin ohjata resursseja, ja siten hyödyntää pitkällä aikavälillä sekä luonnonsuojelua että aluetaloutta.

\section{Kosteikkojen ennallistaminen ja hoito}

Taajamien jätevesien päästöt sekä maatalouden ja ojitettujen soiden ravinnehuuhtoumat ovat aiheuttaneet rehevöitymistä, joka näkyy muun muassa kosteikkojen umpeenkasvuna ja veden samentumisena ${ }^{21}$. Kosteikkojen rehevöitymisen seurauksena kasvilajisto ja kalayhteisö yksipuolistuu, rannat ja niityt valtaa yhtenäinen järviruovikko ja monien vesilintulajien kannat pienenevät. Särkikalat vähentävät pohjaeläinlajistoa, joka puolestaan on monien taantuneiden vesilintulajien ravintoa ${ }^{22}$. Alempien ravintoketjun tasojen muutokset ja kohteiden umpeenkasvu heijastuvatkin vähenevinä ja uhanalaistuvina vesilintukantoina, joka tuo haasteen myös kestävälle metsästykselle. Ympäristöministeriön Helmi-ohjelmassa kunnostetaan kymmeniä valtakunnallisesti tärkeitä lintuvesiä ja maa- ja metsätalousministeriön Sotka-hankkeessa perustetaan kymmeniä uusia riistakosteikkoja ${ }^{23,24}$. Hoitotoimilla tiedetään aikaisempien tutkimusten perusteella olevan nopeita vaikutuksia lintumääriin, ja ne voivat vaikuttaa positiivisesti meriekosysteemiin vähentämällä rehevöitymistä ${ }^{25}$.

Hoitotoimien rahoittaminen itsessään elvyttää taloutta työllistämällä niiden suunnittelusta, konkreettisista toimenpiteistä ja seurannasta vastaavia henkilöitä. Lisäksi hoitotoimiin voidaan yhdistää myös muuta elinkeinonharjoitusta: i) Kosteikkojen umpeenkasvua voidaan torjua niittämällä järviruovikkoa, jota voidaan hyödyntää esimerkiksi turpeen korvikkeena puutarhakäytössä ${ }^{26}$, ii) Laidunnus on tehokas keino torjua umpeenkasvua $25,27,28$, joten eettisempää ja luonnon monimuotoisuutta edistävää niittylaidunnusta tulisi 
edistää, iii) Ruoppausta voidaan käyttää myös kosteikkojen umpeenkasvun torjunnassa, jolloin poistettua vesisammalta voidaan käyttää teollisessa harmaavesisuodatuksessa ${ }^{29,30}$ ja iv) Hoitokalastus on tehokas tapa poistaa vesistöstä ravinteita ja kasvattaa esimerkiksi harvinaistuvien vesilintujen ravinnoksi sopivien selkärangattomien ja kasviravinnon määrää ${ }^{31}$. Lisäksi särkikalakantojen taloudellinen hyödyntäminen on nouseva ilmiö. Uusia tuotteita tulee säännöllisesti markkinoille perinteisten kalatuotteiden rinnalle. Etenkin matalia merenlahtia voidaan kunnostaa toimenpiteillä, joilla hauen kutu onnistuu paremmin, mikä parantaa niin kaupallista kalastusta kuin virkistyskalastusta ${ }^{32}$. Edellä mainituilla hoitotoimilla voidaan parantaa kosteikkojen luonnontilaa, luoda taloudellista toimeliaisuutta sekä edistää hyvinvointia virkistyskäytön kuten valokuvauksen, linturetkeilyn ja metsästyksen lisääntyessä.

\section{Soiden suojelu ja ennallistaminen}

Viime vuosikymmenen aikana suolajiston tila on heikentynyt selvästi suoelinympäristöjen ojituksen ja turpeennoston takia ${ }^{33}$. Soita voitaisiin laajamittaisesti ennallistaa, kuten ympäristöministeriön Kestävä elvytys -raportissa on ehdotettu ${ }^{5}$. Laajamittainen kansallinen ennallistamisohjelma mahdollistaa oikeudenmukaisen elvytysrahojen käytön, koska ennallistamista voidaan kohdentaa alueille, joilla esimerkiksi turvetuotannosta luopuminen aiheuttaa merkittäviä paikallisia vaikutuksia. Suomessa arvioidaan olevan noin miljoona hehtaaria puuntuotannollisesti kannattamattomia ojitusalueita. Näistä noin 200000 hehtaaria on rehevyytensä puolesta alueita, joilla ennallistaminen tuottaa parhaat luonnon monimuotoisuusvaikutukset ${ }^{34}$. Ennallistamisen työllisyysvaikutusten on arvioitu olevan noin 10 henkilötyövuotta 1000 ennallistettua hehtaaria kohti sisältäen suunnittelun ja toteutuksen ${ }^{34}$.

Soiden ennallistamisen luontovaikutukset ovat lupaavia ja suon keskeisten toimintojen kannalta oleellinen eliöyhteisön rakenne saadaan hyvällä todennäköisyydellä palautettua. IIman aktiivisia ennallistamistoimia luontovaikutukset sen sijaan jäävät vaatimattomammiksi ${ }^{34}$. Soiden ennallistamisen ilmasto- ja vesistövaikutukset riippuvat kohteesta, joten ennallistettavien kohteiden priorisointi on tärkeää. Ennallistamisen seurauksena vedenpinta nousee ja hapeton turvekerros kasvaa, mikä johtaa metaanipäästöjen kasvuun. Rehevien soiden ennallistaminen näyttäisi tuovan ilmastohyötyjä noin kahdessakymmenessä vuodessa. Karumpien soiden ennallistaminen tuottaa ilmaston kannalta negatiivisia vaikutuksia paljon pidempään ja vaikutukset kääntyvät ilmastohyödyiksi vasta pitkällä aikavälillä ${ }^{34}$. Ennallistamisen vesistövaikutus on hetkellisesti negatiivinen erityisesti rautapitoisilla ja rehevillä mailla, kun taas karun suotyypin suot ovat tässä suhteessa turvallisempia ennallistettavia. Ennallistamisella saadaan palautettua suon virkistyskäyttö metsästykseen, marjastukseen ja retkeilyyn, joilla on myönteisiä vaikutuksia ihmisten hyvinvointiin ja terveyteen ${ }^{34}$. Ennallistamisen rinnalla pitää kiinnittää huomiota myös soiden suojeluun. Ojitusta, turvetuotantoa tai maa- ja metsätaloutta ei tulisi sallia luonnontilaisilla tai vain vähän heikennetyillä soilla, joiden lajisto ja muut luontoarvot ovat vielä tallella.

\section{Vesistöjen vaellusesteiden purku}

Suomen vesivoimalaitoksista 65 prosenttia on pieniä ja ne muodostavat yhteensä vain 5 prosenttia vesivoimasähkön kokonaistehosta ${ }^{35}$, mutta ne toimivat merkittävinä vaellusesteinä kaloille. EU:n biodiversiteettistrategian tavoitteena on vapauttaa $25000 \mathrm{~km}$ jokia EU:n alueella vapaana virtaaviksi ${ }^{7}$. Purkamalla investointisyklin loppupäässä olevia pieniä ja sähköntuotannon kannalta vähämerkityksellisiä voimaloita ja muita vaellusesteitä voidaan elvyttää sekä vaelluskalakantoja, virtavesiekosysteemejä että taloutta. Tähän toimenpiteeseen voidaan suunnata resursseja esimerkiksi maa- ja metsätalousministeriön käynnistämän NOUSU-ohjelman kautta ${ }^{36}$. Vaellusesteitä purkamalla ja kalojen lisääntymisalueita kunnostamalla voidaan suoraan parantaa virtavesielinympäristöjen tilaa ja ekosysteemitoimintoja sekä samalla tukea paikallista työllisyyttä ja maisema-, virkistys- ja luontoarvoja. Yhdysvaltojen kokemusten perusteella väliaikaisten työllisyysvaikutusten suuruusluokka on noin 11-26 henkilötyövuotta miljoonaa euroa kohden ${ }^{37}$. Virtavesien kunnostus luo edellytyksiä pysyvien työpaikkojen synnylle esimerkiksi matkailuun ja kalastukseen, ja se luo myös hinnoittelemattomia virkistyshyötyjä ${ }^{38,39}$. 


\section{Ilmastonmuutos ja luonnon monimuotoisuus}

Ilmastonmuutos on suuri uhka luonnon monimuotoisuudelle ja siksi ilmastonmuutoksen hidastaminen on myös luonnon monimuotoisuuden turvaamista. Kaikilla eliölajeilla on oma ilmastolokeronsa, joka määrittelee lajin levinneisyyttä ja runsautta suhteessa ilmastoolosuhteisiin. Ilmaston muuttuessa lajit voivat reagoida kolmella eri tavalla: i) sopeutua muutokseen, ii) siirtyä muuttuvien ilmasto-olosuhteiden mukana kohti napa-alueita tai vuoristojen lakia tai iii) kuolla sukupuuttoon ${ }^{40,41}$. Nykyinen ilmastonmuutoksen etenemisvauhti on todennäköisesti valtaosalle lajeista liian nopea, jotta ne voisivat sopeutua evolutiivisesti. Sen sijaan lajien levinneisyysalueet muuttuvat, ja esimerkiksi hyönteisten ja lintujen levinneisyysalueet ovat Suomessakin siirtyneet huomattavasti kohti pohjoista ${ }^{42,43,44}$. Lajien levittäytyminen uusille alueille ei ole itsestäänselvyys vaan edellyttää, että sopivaa elinympäristöä, jota pitkin levittäytyä, on riittävästi. Itämeri on yksi nopeimmin lämpenevistä meristä ja herkkää meriluontoa rasittaa lisäksi rehevöityminen. Sadannan lisääntyessä suolaisuus laimenee ja johtaa mereisten- ja makeanvedenlajien levinneisyysalueiden muutoksiin ${ }^{45,46,47}$.

IImastonmuutos tuo mukanaan uusia tulokaslajeja, joihin sisältyy riski tuholaisista ja taudeista, jotka voivat olla haitallisia sekä luonnon monimuotoisuudelle että maamme taloudelle. Luontaisten elinympäristöjen vähenemisen ja ilmastonmuutoksen yhdysvaikutus on tällä hetkellä merkittävä uhka luonnon monimuotoisuudelle ${ }^{40,48,49}$. Ensimmäiset ilmastonmuutoksen aiheuttamat sukupuutot on havaittu jo yli kymmenen vuotta sitten trooppisilla alueilla ${ }^{40}$. Suomalaisten tutkimusten ${ }^{50,51,52,53,54,55}$ mukaan etenkin pohjoiset lajit, esimerkiksi tunturiympäristöjen lajit, voivat kadota, mutta näiden lajien hiipumista voidaan estää hyvälaatuisilla ja topografisesti vaihtelevilla kytkeytyneillä elinympäristöillä, kuten suojelualueilla. Vastaavasti elinolosuhteiltaan vaateliaammat eteläiset lajit tarvitsevat hyvälaatuisia elinympäristöjä astinkivinään levittäytyessään kohti pohjoista. Ilmastonmuutos lisää myös haitallisten vieraslajien leviämisen todennäköisyyttä ${ }^{56}$. Vieraslajien torjunta onnistuu helpoiten leviämisen alkuvaiheessa, ja edellyttää ajantasaisesti toimivaa havaintojen keräämistä sekä nopeita ja tehokkaita torjuntatoimia.

\section{Metsissä tehtävät monimuotoisuustoimet}

Suomalainen metsäluonto on vuosikymmenien talouskäytön seurauksena suuresti muuttunut. Vaikka suojeltujen metsien määrä on hieman lisääntynyt METSO-ohjelman myötä, metsien jatkuva heikentäminen on mittakaavaltaan moninkertaista suojelutoimiin verrattuna. Kolmasosa Suomen uhanalaisista lajeista on metsälajeja ja viimeisimmän uhanalaisuusarvioinnin perusteella uhanalaistuminen on edelleen hieman lisääntynyt. Uhanalaistumiskehitykseen vaikuttavat metsien käyttöön suoraan tai välillisesti liittyvät toimet, etenkin puulajisuhteiden muutokset, vanhojen metsien hävittäminen, kookkaiden puiden vähentäminen sekä lahopuun hävittäminen ${ }^{33,57}$.

Metsien hakkuilla on myös epäsuoria vaikutuksia monimuotoisuuteen ilmastovaikutuksen kautta, sillä avohakattu metsä muuttuu hiilen nielusta hiilen lähteeksi seuraavien vuosikymmenien ajaksi hakkuutähteistä ja maaperästä vapautuvan hiilen vuoksi, ja hakkuukertymän hiilestä merkittävä osa vapautuu ilmakehään lyhyessä ajassa, eikä kasvava metsä saavuta ennen hakkuuta vallinnutta hiilen varastoa vielä useisiin vuosikymmeniin ${ }^{58,59}$. Metsien tilan parantamiseksi KEMERA-tuet voisi kohdentaa luonnon monimuotoisuuden ja ilmaston suojeluun, esimerkiksi suuntaamalla ne vesiensuojelutoimiin (kuten kosteikot, putkipadot), 
valuma-aluekohtaisiin vesiensuojelusuunnitelmiin, metsäammattilaisten täydennyskoulutushankkeisiin ja metsänhoitotoimiin, joissa selvästi pyritään turvaamaan sekä ilmasto- että monimuotoisuusnäkökulmat, sekä talousmetsissä jatkuvan kasvatuksen kohteisiin ja kiertoajan pidentämiseen. Osana kestävää elvytystä metsissä tehtävillä monimuotoisuustoimilla sekä hakkuutapoja monipuolistamalla voidaan parantaa metsäekosysteemien tilaa ja samalla luoda mahdollisuuksia uusille elinkeinoille esimerkiksi matkailussa ja metsien virkistyskäytössä ${ }^{60,61,62}$. EU:n biodiversiteettistrategian mukaan vähintään 30 prosenttia maa- ja merialueista tulee määrittää suojelualueiksi? METSO-ohjelman kokonaistavoite tulisi tämän EU:n biodiversiteettistrategiassa määritellyn suojelutavoitteen myötä moninkertaistaa, sen resursseja vastaavasti kasvattaa ja laajentaa ohjelma kattamaan koko Suomi. Erityisen kiireellistä on turvata myös Pohjois-Suomen jäljellä olevien vanhojen metsien säästyminen hakkuilta.

\section{Investointi ympäristökansalaisuuden ylisukupolviseen vahvistamiseen}

Ymmärrys ihmiskunnan riippuvaisuudesta luonnon ekosysteemien hyvinvoinnista on keskeinen lähtökohta ympäristöstä huolehtimiselle ${ }^{4}$. Esimerkiksi yhteiskunnallinen asema, koulutusala, elämäntilanne, ikä, asuinpaikkakunta, kulttuurinen tausta, oma kiinnostus ja poliittinen suuntautuminen ${ }^{63,64}$ vaikuttavat merkittävästi kansalaisten mahdollisuuksiin muodostaa tietopohjainen suhde ilmastonmuutokseen ja luontokatoon kytkeytyviin monimuotoisiin ja -mittakaavaisiin ympäristökysymyksiin. Tällä hetkellä osalla Suomen väestöstä on heikot mahdollisuudet ymmärtää näitä ilmiöitä ja niiden kytkeytymistä muihin megatrendeihin, kuten kansainväliseen muuttoliikkeeseen ja kaupungistumiseen. Tämä tarkoittaa, että heidän on vaikea toimia tietoperustaisesti ympäristökansalaisina. Vastakkainasetteluja rakentuu helposti, mikä heikentää ympäristövastuullisen kansalaisyhteiskunnan kehitystä $65,66,67$. Tilannetta voidaan parantaa tukemalla kattavaa ympäristökasvatustoimintaa.

Ympäristökasvatuksen edistäminen on kirjattu Sanna Marinin hallitusohjelmaan ${ }^{10}$, opetus- ja kulttuuriministeriön hallinnonalan kestävän kehityksen linjauksiin ${ }^{68}$, jotka koskevat kaikkia koulutuksen tasoja, sekä voimassa oleviin opetussuunnitelmien perusteisiin eri oppiasteilla. Koska ympäristökasvatus ei kiinnity tiettyyn oppiaineeseen tai tieteenalaan vaan on luonteeltaan läpileikkaavaa, vaatii sen toteuttaminen esimerkiksi koulutusyksiköissä uudenlaista työn järjestelyä ja monialaista yhteistyötä. Ympäristökasvatukseen tulisi investoida eri koulutusasteilla varhaiskasvatuksesta perusopetukseen, toisen asteen koulutuksesta korkeakoulutukseen ja elinikäiseen oppimiseen. Suomessa koulutus saavuttaa kaikki väestöryhmät, minkä vuoksi investoiminen ympäristökasvatukseen parantaa kaikkien kansalaisten valmiuksia ymmärtää hyvinvoinnin ja luonnon säilyttämisen välistä riippuvuutta. Elvytystoimet voitaisiin kohdistaa paitsi institutionaaliseen koulutussektoriin, myös järjestötoimintaan. Ympäristökasvatusta antavat ja kehittävät yhteistyössä julkisen ja yksityisen sektorin kanssa lukuisat järjestöt, yhdistykset ja ryhmät. Ympäristökasvatus elvytystoimena kytkeytyy useisiin muihin tässä kannanotossa esitettyihin elvytystoimiin, jolloin niihin panostaminen samanaikaisesti voi lisätä toimien vaikuttavuutta.

\section{Luontopohjaiset ratkaisut kaupunkirakenteessa}

Osana kestävää elvytystä voidaan edistää luontopohjaisia ratkaisuja ja tukea uusien lähivihreäratkaisujen kehittämistä sekä olemassa olevien ratkaisujen laajentamista ${ }^{5}$. EU:n biodiversiteettistrategian mukaan jokaisen yli 20000 asukaan kaupungin olisi tehtävä viheraluesuunnitelma vuoden 2021 loppuun mennessä ${ }^{7}$. Näiden suunnitelmien resursoinnin turvaaminen edesauttaisi kaupunkiluonnon tilan arviointia, seurantaa ja monimuotoisen luonnon säilyttämisen edistämistä kaupunkialueilla, joilla suurin osa suomalaisistakin asuu. Kaupunkien viheraluesuunnittelussa keskitytään pääsääntöisesti uusien rakennettujen viheralueiden luomiseen, mutta siinä ei automaattisesti huomioida rakentamisen alle jäävän luonnon tai viheralueiden supistumista. Kunnianhimoisetkaan viherryttämissuunnitelmat - kuten Helsingin kaupungin tavoite istuttaa 100000 puuta - eivät tue kokonaisheikentymättömyyttä, mikäli rakentamisen aiheuttama luontohaitta ylittää viherryttämisen tuoman luontohyödyn. Luonnontilaisen kaltaisia ympäristöjä ei tulisi korvata rakennetulla puistolla tai pihoilla, sillä luonnon monimuotoisuusarvot jäävät rakennetuilla viheralueilla vähäisemmiksi.

Hallittu hoitamattomuus tukee luonnon monimuotoisuutta vaarantamatta asukkaiden virkistyskäyttöä. Ihmisen viheralueilta saamat terveyshyödyt vaikuttavat olevan suurempia monimuotoisilla alueilla ${ }^{69}$. Mikrobiologisen monimuotoisuuden vähäisyys kaupunkiympäristössä on pääsyitä immuunivälitteisiin 
sairauksiin ${ }^{70,71,72}$, joten mikrobiologista monimuotoisuutta kaupallisesti tuottamalla ja suunnitellusti lisäämällä tai vaalimalla voidaan saavuttaa hyvinvointia ja taloudellisia säästöjä. Rakennettujen viheralueiden monimuotoisuutta voidaan parantaa rakentamalla hulevesien imeyttämiseksi kosteikkoja, jättämällä kuolleet kasvinosat lahoamaan puistoihin, valitsemalla istutuksiin vain luontaisesti kotimaisia kasvilajeja tai asukkaiden hyötykäyttöön soveltuvia hedelmäpuita, lisäämällä kasvillisuuden kerroksellisuutta ja muuttamalla ruohokentät niityiksi. Luonnon kannalta pienetkin kaupunkien vihersaarekkeet, joutomaat ja jopa yksittäiset kookkaat puut ovat merkityksellisiä, joten ne tulisi säästää tai niiden heikentämistä tulisi aktiivisesti välttää. Viherkattojen ja -seinien rakentamisella voidaan myös osaltaan monipuolistaa kaupunkiluontoa. Jos kaupunkirakenteen kehittämisessä on välttämätöntä heikentää olemassa olevaa luontoa, tulisi kokonaisheikentymättömyyden tavoitteen mukaisesti haitta kompensoida ennallistamalla luontoa toisaalla.

\section{Lämmitystapojen muutokset}

Lämmityksen päästöjä voidaan alentaa vähentämällä fossiilisen polttoöljyn käyttöä, parantamalla rakennusten energiatehokkuutta ja investoimalla turve- ja kivihiilivoimaloita korvaaviin syvämaalämpöhankkeisiin. Ilmastopaneeli on ehdottanut elvytystoimina nopeutettua öljylämmityksestä luopumista, asuntojen energiatehokkuuden parantamista ja syvämaalämpöhankkeen pilottia ${ }^{6}$. Näillä toimilla on arvioitu olevan selvä kasvihuonekaasupäästöjä vähentävä vaikutus ${ }^{6,75}$, mikä vaikuttaa luonnon monimuotoisuuteen positiivisesti. Syvämaalämpöhankkeen korvatessa turpeen polttoa ja kysyntää sillä on suora positiivinen vaikutus monimuotoisuuteen, kun turvetuotantoalueet voidaan ennallistaa tai jättää palautumaan kohti luonnontilaa. Toimilla on myös epäsuoria myönteisiä vaikutuksia luonnon monimuotoisuuteen, sillä fossiilisten polttoaineiden polton aiheuttamat ilmansaasteet saattavat heikentää kasvien kasvua ja elinvoimaisuutta sekä köyhdyttää kasviyhteisön monimuotoisuutta (ks. s. 10).

\section{Puun käytön lisääminen rakentamisessa}

Puun käytön lisääminen rakentamisessa, etenkin julkisessa rakentamisessa ja kaupunkirakentamisessa, kuten ympäristöministeriön Kestävä elvytys -raportissa ehdotetaan, kasvattaa hiilen melko pitkäaikaisia varastoja ja tukee siten ilmastonmuutoksen hillintää ${ }^{5}$. Ilmastotavoitteiden kannalta vielä olennaisempaa on, että puu korvaa rakennusmateriaalina betonia, jonka valmistus on merkittävä kasvihuonekaasupäästöjen lähde ${ }^{73}$. Puurakentaminen ja siihen liittyvän teknologian kehittäminen parantaa puun käytön materiaalitehokkuutta ja asettaa myös vaatimuksia puun laadulle. Siirtyminen korkeamman jalostusasteen puutuotteisiin hyödyttää sekä taloutta että luontoa: kotimainen rakennuspuutuotanto ja puurakentaminen sekä siihen liittyvän osaamisen kehittäminen edistävät työllisyyttä ja vientimahdollisuuksia samalla kun edistetään hiilen sidontaa ja siirrytään kohti materiaali-intensiivisempää tuotantoa ${ }^{74}$. Tämä voi vähentää hakkuupaineita ja tukea siirtymää metsien jatkuvan kasvatukseen. Puurakentamisen edistämisessä tulisi kuitenkin pitää huoli siitä, ettei metsänhakkuiden kokonaismäärä lisäänny. Tämä edellyttää, että rakennuspuun lisääntynyt tarve otetaan alemman jalostusasteen puutuotteiden tuotannosta.

\section{0a ja 10b. Rautatie- ja raitiotieinvestoinnit}

Suomen siirtymistä hiilineutraaliuteen voitaisiin edistää investoimalla rauta- ja raitioteihin. Suomen ilmastopaneelin mukaan kaupunkien pikaraitiotiehankkeilla, joissa valtio sijoittaisi hankkeiden rakentamisvaiheen tukemiseen, on kohtalainen kasvihuonekaasupäästöjä vähentävä vaikutus niiden korvatessa henkilö- ja linja-autoliikennettä ${ }^{6}$. Hankkeiden elvytysvaikutus arvioidaan erittäin hyväksi, koska ehdotettu toteutustapa kannustaa myös yksityisiin investointeihin. Pikaraitioteiden ja uusien rataosuuksien rakentaminen edellyttää maankäyttöä, joka voi uhata luonnon monimuotoisuuden kannalta tärkeitä alueita (10a kuvassa 1, s. 3). Rakentamisen aiheuttamat luontohaitat voidaan hyvittää budjetoimalla elvytystoimiin mukaan haittojen hyvitys eli ekologinen kompensaatio (ks. s. 4). Tämä loisi luonnollisen kannusteen välttää turhien luontohaittojen aiheuttamista. Kompensaatiot toteutetaan ennallistamalla ja suojelemalla ekosysteemejä, ja ennallistamistoimilla on suora elvytysvaikutus. Vaatimalla haittojen ylikompensaatiota saadaan luonnon tilaa parannettua (10b kuvassa 1, s. 3) ja työllistävään ennallistamistoimintaan kohdistuu enemmän rahaa. 


\section{Ilmansaasteet ja luonnon monimuotoisuus}

IImansaasteet vaikuttavat suoraan ja epäsuorasti maa- ja meriluonnon monimuotoisuuteen $^{76}$. Ihmisen toiminta (esimerkiksi teollisuus, liikenne, asuminen ja jätehuolto) aiheuttaa ilmanlaatua heikentäviä päästöjä, joista tärkeimmät ovat rikin ja typen oksidit, pienhiukkaset ja kasvihuonekaasut. Kasvillisuus puolestaan tuottaa ilmakehän hapen, sitoo hiiltä ja puhdistaa ilmaa. Kasvillisuuden määrä ja laatu vaikuttavat hilitasapainon säätelyyn. Maa- ja metsätaloudella on myös suoria vaikutuksia ilman epäpuhtauksiin. Voimakas lannoittaminen lisää maaperän kaasumaisia typpipäästöjä, jotka huonontavat paikallisesti ilman laatua esimerkiksi alailmakehän otsonimuodostuksen kautta ${ }^{77}$. Kaikki toimenpiteet, joilla näitä päästöjä voidaan vähentää, vähentävät haitallisia vaikutuksia luonnon monimuotoisuuteen.

IImansaasteet häiritsevät ekosysteemien toimintaa. Esimerkiksi kohoava otsonitaso heikentää kasvien kasvua, elinvoimaisuutta ja hiilen sidontaa sekä köyhdyttää kasviyhteisön monimuotoisuutta ${ }^{78}$. Nämä muutokset johtavat hyönteisten määrän alenemiseen, pölytystoiminnan heikkenemiseen sekä maaperän ravinnekiertojen muutoksiin.

Ekosysteemin hiilensidontakyky heikkenee ${ }^{78}$. Jopa pienet saastepitoisuudet vaikuttavat kasvien lisääntymiseen ja mikrobiyhteisöjen koostumukseen ${ }^{79,80,81}$. Luonnossa monet ympäristötekijät vaikuttavat samanaikaisesti, monimutkaisten yhdysvaikutusten kautta.

Ilmansaasteilla (esimerkiksi typpidioksidi $\mathrm{NO}_{2}$ ja pienhiukkaset) voi pieninä pitoisuuksina olla myös kasvua edistäviä lannoittavia vaikutuksia ${ }^{82,83}$. Typpilaskeuman aiheuttama maaperän rehevöityminen vaikuttaa kasvillisuuteen, ja heijastevaikutukset näkyvät myös kasvinsyöjähyönteisten runsaussuhteiden muutoksina ${ }^{84,85}$. Metsäpalot lisäävät ilman saastumista, mutta toisaalta edistävät luonnon monimuotoisuutta esimerkiksi lisäämällä kuollutta puuta. Ilmansaasteet vaikuttavat myös vesiekosysteemeihin ravinnekiertojen muutosten, haitta-aineiden (kuten elohopea) sekä happamoitumisen johdosta. IImansaasteet heikentävät ihmisten terveyttä ja hyvinvointia suoraan huonontamalla hengitysilman, veden ja ravinnon laatua, mutta myös välillisesti heikentyneen luonnon monimuotoisuuden, ekosysteemipalveluiden, kasvituotannon ja raaka-aineiden kautta ${ }^{86,97,88}$.

\section{Biokaasutuotannon edistäminen maataloudessa}

Bioenergian tuotannolla on todettu olevan ristiriitaisia vaikutuksia biodiversiteettiin sekä globaalisti että alueellisesti, riippuen alkuperäisestä maankäytöstä, tuotannon mittakaavasta sekä käytännön menetelmistä89. Lauhkeilla alueilla vaikutukset biodiversiteettiin on raportoitu tai ennustettu negatiivisiksi johtuen bioenergian tuotantoon liittyvistä puoliluontaisten habitaattien menetyksistä, keinolannoitteiden ja kasvinsuojelumyrkkyjen käytön lisääntymisestä sekä nurmituotannon tehostumisesta. Pohjoismaille on kuvattu muutama tapa tuottaa bioenergiaa, joilla on potentiaalisesti neutraaleja tai positiivisia vaikutuksia luonnon monimuotoisuuteen ${ }^{90}$. Esimerkkinä tästä on kasvibiomassan korjaaminen puoliluontaisilta alueilta (kuten johtoaukeat ja perinnebiotoopit) tavalla, joka ottaa huomioon niiden lajiston ${ }^{90,91}$. Tämän toimenpiteen taloudellinen potentiaali on kuitenkin kyseenalainen. Mikäli biomassaa kasvatetaan erikseen biokaasutusta varten, voidaan ajautua tilanteeseen, jossa biokaasun tuotanto kilpailee viljelyn tai rehuntuotannon kanssa johtaen uusien maa-alueiden raivaamiseen pelloiksi. Lisäksi biomassojen viljelyn maaperävaikutukset voivat nousta suuriksi eritoten turvemailla tai alueilla, joilla vaihtoehtoinen maankäyttö esimerkiksi metsänä toisi paremman ilmastovaikutuksen. Positiivisia epäsuoria vaikutuksia ilmastomuutoksen hidastamisen kautta on löydetty etenkin toisen sukupolven biopolttoaineilla, kuten elintarviketeollisuuden jätteillä. Aitojen sivuvirtojen käyttö on luonnon monimuotoisuuden kannalta neutraalia, mutta niillä on vain rajattu potentiaali ${ }^{90}$. Lannan ja erityisesti lietteen käyttäminen biokaasun tuotannossa ja sen paikallinen käyttö 
maatilalla tai maatilaklusterissa on todennäköisesti monimuotoisuuden kannalta epäsuorasti hyväksi ilmastonmuutoksen hillinnän ja mahdollisesti myös ravinnekuormituksen vähentymisen johdosta, jos mädäte jatkojalostetaan kierrätyslannoitevalmisteiksi².

\section{Itämeren rehevöityminen ja luonnon monimuotoisuus}

Rehevöityminen on yhä yksi vakavimmista Itämeren ympäristöongelmista, joka vaikuttaa lähes kaikkien meren uhanalaisten luontotyyppien uhanalaistumiseen. Vaikka ravinnekuormitus on viime vuosikymmenien aikana vähentynyt, Helsingin komission (HELCOM) mukaan yli 97 prosenttia alueesta kärsii entisestä ja nykyisestä typpi- ja fosforikuormasta, 12 prosenttia alueesta on huonoimmassa luokituksessa, eikä Itämeren suojelun toimintaohjelman (BSAP) tavoitteita todennäköisesti tulla saavuttamaan vuoteen 2021 mennessä97. Suomen osalta erityisen huolestuttava on Saaristomeren tila, joka on yhä HELCOM:in saastuneiden merialueiden hot spot -listalla maalta tulevan kuormituksen ja heikon ekologisen tilan vuoksi98.

Itämeressä on vähäsuolaista murtovettä, minkä vuoksi monet Itämeren selkärangattomat ja kalalajit elävät lähellä fysiologisen sietokykynsä äärirajoja lämpötilan ja suolaisuuden suhteen. Tämän vuoksi Itämeren luonnon monimuotoisuus on erityisen herkkä rehevöitymisen vaikutuksille, kuten happikadolle, suurille leväkukinnoille ja myrkyllisille sinileville. Vähäisen lajimäärän vuoksi systeemin sietokyky on matala, sillä kourallinen lajeja tuottaa eri ekosysteemien keskeisiä funktioita, jotka menetetään, jos nämä avainlajit häviävät. Ilmastonmuutos lisää typen ja fosforin kuormitusta, pahentaa Itämeren rehevöitymistä ja vaikuttaa suolapitoisuuden laimenemisen sekä meren happamoitumisen kautta lajien levinneisyyteen ja ekosysteemitoimintoihin, ja tätä kautta ihmisiin ${ }^{99,100,101}$.

\section{Merituulivoima}

Ilmastonmuutoksen torjuminen vaatii energiajärjestelmän perusteellista rakennemuutosta ja uusien teknologioiden kuten merituulivoiman käyttöönottoa. Valtio voi osana vihreää elvytyspakettia käynnistää merituulivoimalan pilottihankkeen, kuten Suomen ilmastopaneeli on ehdottanut ${ }^{6}$. Kotimaisen merituulivoiman lisääminen syrjäyttää alkuvaiheessa fossiilista energiantuotantoa ja edesauttaa teollisuuden sähköistymistä, jolloin sillä on positiivisia epäsuoria vaikutuksia luonnon monimuotoisuuteen vähentyneiden kasvihuonekaasupäästöjen kautta (ks. s. 7). Tuulivoiman rakentaminen merialueilla vähentää maankäyttöä, mutta lisää meriluontotyyppeihin kohdistuvaa painetta. Lisäksi vedenalainen melu voi olla haitallista vedenalaiselle ekosysteemille varsinkin rakennusvaiheessa ${ }^{93}$. Merituulivoiman haittavaikutuksia monimuotoisuudelle voi lieventää merialuesuunnittelulla, jolla huolehditaan, että voimaloita ei rakenneta luonnon monimuotoisuuden kannalta tärkeille merenalaisille matalikoille ja muutoin herkille alueille, vaan kauemmas rannasta ${ }^{93,94}$. Elvytysvaikutuksen kannalta keskeistä on, kuinka paljon yksityisiä investointeja saadaan mukaan osaksi julkista elvytyspakettia. Merituulivoiman tuet voidaan jakaa uusiutuvan energian tarjouskilpailulla, jolla voidaan edesauttaa julkisten elvytysvarojen tehokasta kohdentamista. Merituulivoiman rakentamisesta aiheutuvat luontohaitat tulee hyvittää ottamalla käyttöön ekologiset kompensaatiot (ks. s. 4).

\section{Iso aurinkovoimala}

Osana vihreää elvytystä Suomeen voidaan rakentaa yksi tai useampia aurinkovoimaloita. Aurinkovoimalahankkeet eivät ole tähän mennessä osallistuneet teknologianeutraaliin uusiutuvan energian tuen tarjous- 
kilpailuun, mutta niiden rakentamista olisi mahdollista edistää omalla, vain aurinkovoimalle kohdennetulla tuella. Ilmastopaneeli on arvioinut, että aurinkovoimalainvestoinnit johtaisivat kasvihuonekaasupäästöjen maltilliseen vähenemiseen, mutta päästövähennys tukea kohti on arvioitu pienemmäksi kuin merituulivoimassa $^{6}$. Sijoituspaikasta riippuen suuren aurinkovoimalan vaatima maankäyttö voi aiheuttaa ekosysteemien heikentymistä. Haittoja voidaan välttää sijoittamalla voimalat jo valmiiksi rakennettuun ympäristöön, kuten katoille, tai edistämällä hajautettua aurinkovoimaa yksittäisten kotitalouksien ja pienyhteisöjen uusiutuvan energiantuotannon kautta ${ }^{95}$. Jäljelle jäävät luontohaitat voidaan hyvittää ottamalla käyttöön ekologiset kompensaatiot (ks. s. 4).

\section{Metsien käyttöä lisäävät biojalostamohankkeet}

Varsinkin kuitupuusta tehtävän sellun valmistamiseen tähtäävät biojalostamohankkeet nousevat aika-ajoin keskusteluun mahdollisina astinkivinä kohti vähähiilisyyttä. Puubiomassalla voidaan korvata fossiilisia tuotteita ja polttoaineita, mutta mikäli biotuotetehdas lisää metsänhakkuita, kokonaisvaikutus on luontohaittoja lisäävä ja ilmastoa lämmittävä aikajänteellä, jolla tavoiteltuja ilmastotoimia pyritään saamaan aikaan ${ }^{58,59}$. Metsien lajit ja luontotyypit kärsivät jo nykytason mukaisista hakkuista ${ }^{33,96}$, joten biojalostamo-hankkeiden tulisi korvata vanhaa tehdaskantaa hakkuita lisäämättä. Uusien tehtaiden ympärille vaadittavat muut hankkeet, kuten tiet, syväväylät, liikenteen lisääntyminen ja tehtaiden vesistöpäästöt aiheuttaisivat väistämättä luontohaittaa. Jos uusia biojalostamoita suunnitellaan, on lisääntyvän metsien hakkuun vaikutukset metsäluonnon köyhtymiseeen ja vesistöihin otettava huomioon. Biotuotetehtaiden luontohaittaa voidaan vähentää huolehtimalla, että puunkäyttö ei ylitä alueellista suurinta ekologisesti kestävää hakkumäärää. Tämän lisäksi puiden hankinnan tulisi kohdentua tiukasti sertifoituihin (FSC) metsiin. Hakkuiden aiheuttamien haittojen ulkoistamisen estämiseksi ulkomaisen puun käytölle on oltava voimassa tiukat kestävyyskriteerit. Luontopaneeli katsoo, että biojalostamohankkeiden ei tulisi vesistö-, luonto-, ja ilmastovaikutuksiensa vuoksi lähtökohtaisesti kuulua vihreillä elvytysrahoilla tuettaviin hankkeisiin. Jos tällaisia hankkeita kuitenkin tuetaan, tulisi samalla velvoittaa hankkeiden kokonaisvaltainen luonto- ja ilmastohaittojen arviointi ja kompensointi (ks. s. 4). 


\section{LÄHTEET}

1 Suomen Pankki. 2020. Suomen talouden väliennuste, syyskuu 2020.

https://www.eurojatalous.fi/fi/2020/artikkelit/suomen-talouden-valiennuste-syyskuu-2020-taantumaa-seuraa-hidastoipuminen/.

2 Helsinki GSE. 2020. Tilannehuoneen raportti 17.12.2020 - viimeisimmät kehityskulut työmarkkinoilla, kotitalouksissa ja yrityksissä. https://www.helsinkigse.fi/corona/tilannehuoneen-raportti-17-12-2020-viimeisimmat-kehityskuluttyomarkkinoilla-kotitalouksissa-ja-yrityksissa/.

3 World Economic Forum. 2021. The Global Risk Report. https://www.weforum.org/reports/the-global-risks-report-2021.

4 Dasgupta, P. 2021. The Economics of Biodiversity: The Dasgupta Reivew - Full Report. HM Treasury.

5 Ympäristöministeriö. 2020. Kestävä elvytys kohti koronakriisistä toipuvaa, menestyvä ja ekologisesti kestävää Suomea.

6 Ollikainen, M., Seppälä, J., Savolainen, H., Lund, P., Weaver, S., Lounasheimo, J., Sironen, S., Honkatukia, J. \& Arasto, A. 2020. Koronan jälkeinen aika: ilmastotoimet ja vihreä elvytys. Suomen ilmastopaneeli, Raportti 3/2020.

7 Euroopan komissio. 2020. EU:n biodiversiteettistrategia vuoteen 2030. https://ec.europa.eu/info/strategy/priorities2019-2024/european-green-deal/actions-being-taken-eu/eu-biodiversity-strategy-2030 fi.

8 Convention on Biological Diversity (CBD). 2016. Aichi-tavoitteet: https://www.cbd.int/sp/targets/.

9 Valtioneuvosto 2012. Luonnon puolesta - ihmisen hyväksi. Valtioneuvoston periaatepäätös Suomen luonnon monimuotoisuuden suojelun ja kestävän käytön strategiasta vuosiksi 2012-2020. http://www.ym.fi/fiFl/Luonto/Luonnon_monimuotoisuus/Strategia_ja toimintaohjelma.

10 Valtioneuvosto. 2019. Osallistava ja osaava Suomi - sosiaalisesti, taloudellisesti ja ekologisesti kestävä yhteiskunta. Pääministeri Sanna Marinin hallituksen ohjelma 2019. https://valtioneuvosto.fi/marinin-hallitus/hallitusohjelma.

11 Moilanen, A. \& Kotiaho, J. S. 2017. Ekologisen kompensaation määrittämisen tärkeät operatiiviset päätökset. Suomen ympäristö 10/2017. http://urn.fi/URN:ISBN:978-952-11-4754-8.

12 Moilanen, A. \& Kotiaho, J. S. 2018. Fifteen operationally important decisions in the planning of biodiversity offsets. Biological Conservation 227: 112-120. https://www.sciencedirect.com/science/article/pii/S0006320718310668.

13 Moilanen, A. \& Kotiaho, J. S. 2020. Three ways to deliver net positive impact with biodiversity offsets. Conservation Biology, painossa. https://conbio.onlinelibrary.wiley.com/doi/abs/10.1111/cobi.13533.

14 Pekkonen, M., Ryttäri, T., Belinskij, A., Koljonen, S., Mykrä, H., Kostamo, K. \& Ahlroth, P. 2020. Tietotaso ja kokemukset ekologisesta kompensaatiosta Suomessa. Ympäristöministeriön julkaisuja 2020:20.

https://julkaisut.valtioneuvosto.fi/handle/10024/162363.

15 Moilanen, A. \& Kotiaho, J.S. 2020. Vapaaehtoinen ekologinen kompensaatio AA Sakatti Mining Oy:n mahdolliselle Sakatin kaivokselle. https://www.ymparisto.fi/download/noname/\%7B24A97BEE-81E4-492F-AE1CBD4B696629A3\%7D/164286.

16 Matkailutilinpito. 2020. Matkailun talous- ja työllisyysvaikutukset 2017-2018. Visit Finlandin tutkimuksia.

17 Rikkonen, P., Aakkula, J., Niemi, J., Setälä, J., Tyrväinen, L., Viitanen, J., Kniivilä, M., Konu, H., Kurttila, M., Mutanen, A., Niemi, J., Pihlanto, A., Rinne, M., Routa, J., Saarni, K. \& Salmi, P. 2020. Skenaariotarkastelu COVID-19-pandemian vaikutuksista metsäsektoriin, maa-, elintarvike- ja kalatalouteen sekä luontoon perustuvaan matkailu- ja luonnontuotealaan 2020-luvulla. Luonnonvarakeskus.

18 Metsähallitus. 2020. Kansallispuistojen käyntimäärässä kova kasvu - Kansallispuistojen palveluilla selkeä kysyntä. Tiedote, julkaistu 7.9.2020. https://www.metsa.fi/tiedotteet/kansallispuistojen-kayntimaarassa-kova-kasvukansallispuistojen-palveluilla-selkea-kysynta/.

19 Metsähallitus. 2019. Metsähallituksen Luontopalvelujen korjausvelkaselvitys 2018. Metsähallitus Luontopalvelut 2019.

20 Metsähallitus. 2020. Kansallispuistojen retkeilypalvelujen korjausvelkaa kuitataan reilusti - kunnostaminen on sijoitus luontoarvoihin, hyvinvointiin ja työllisyyteen. Julkaistu 13.5.2020. https://www.luontoon.fi/-/kansallispuistojenretkeilypalvelujen-korjausvelkaa-kuitataan-reilusti-kunnostaminen-on-sijoitus-luontoarvoihin-hyvinvointiin-jatyollisyyteen. 
21 Ekholm, P. \& Mitikka, S. 2006. Agricultural lakes in Finland: current water quality and trends. Environ. Monit. Assess. 116: 111-135.

22 Lehikoinen, A., Rintala, J., Lammi, E. \& Pöysä, H. 2016. Habitat-specific population trajectories in boreal waterbirds: alarming trends and bioindicators for wetlands. Animal Conservation 19: 88-95.

23 Ympäristöministeriö. 2020. Helmi-elinympäristöohjelma vahvistaa luonnon monimuotoisuutta. https://ym.fi/helmi.

24 Maa- ja metsätalousministeriö. 2020. Taantuvien riistalintujen kannat nousuun SOTKA-hankkeella. https://mmm.fi/sotka.

25 Lehikoinen, P., Lehikoinen, A., Mikkola-Roos, M. \& Jaatinen, K. 2017. Counteracting wetland overgrowth increases breeding and staging bird abundances. Scientific Reports 7: 41391.

26 John Nurmisen Säätiö. 2020. Rannikkoruokohanke käynnistyi Kirkkonummella - niitolla positiivinen vaikutus Itämereen, ilmastoon ja perinnemaisemiin. https://johnnurmisensaatio.fi/rannikkoruokohanke-kaynnistyikirkkonummella-niitolla-positiivinen-vaikutus-itamereen-ilmastoon-ja-perinnemaisemiin/.

27 Pykälä, J. 2001. Perinteinen karjatalous luonnon monimuotoisuuden ylläpitäjänä. Suomen ympäristö 495: 1-205.

28 Niemelä, M. 2012. Eläimet rantaan - Kyllä vai ei? Opas kestävään rantalaiduntamiseen. Natureship-julkaisuja.

29 Vilpas, R., Kujala-Räty, K., Laaksonen, T. \& Santala, E. 2005. Haja-asutuksen ravinnekuormituksen vähentäminen Ravinnesampo. Osa 1: Asumisjätevesien käsittely. Suomen ympäristö 762.

30 Biolan. nn. Biolan nostaa vesisammalta suodatinmateriaaliksi. https://www.biolan.fi/artikkelit/biolan-nostaavesisammalta-suodatinmateriaaliksi.

31 Sammalkorpi, I., Rintamäki, P. \& Hautala, A. 2020. Ravintoketjukunnostusta linnustonsuojelualueella. Linnut-vuosikirja 2019: 134-137.

32 Vapaa-ajankalastajat. nn. Haukitehtaat. https://www.vapaa-ajankalastaja.fi/vastuullinen/haukitehtaat/.

33 Hyvärinen, E., Juslén, A., Kemppainen, E., Uddström, A. \& Liukko, U.-M. (toim.) 2019. Suomen lajien uhanalaisuus Punainen kirja 2019. Ympäristöministeriö \& Suomen ympäristökeskus. Helsinki.

34 Suomen Luontopaneeli. 2021. Soiden ennallistamisen suoluonto-, vesistö- ja ilmastovaikutukset. Suomen Luontopaneelin julkaisuja 2/2021. (tulossa).

35 Kotiaho, J., Niemelä, J., Sääksjärvi, I.E., Schulman, L., Mönkkönen, M., Boström, C., Jutila, H., Halme, P., Koljonen, S., Oldén, A., Kontula, T., Hautakangas, S. 2019. Elonkirjo ehtyy: suosituksia luonnon monimuotoisuuden turvaamiseksi. Wisdom Letters 1/2019. Jyväskylä: Jyväskylän yliopisto, JYU.Wisdom -School of Resource Wisdom.

https://www.jyu.fi/en/research/wisdom/letters/jyu_wisdom_letter_1_2019.pdf.

36 Maa- ja metsätalousministeriö. 2020. Vaelluskalakantojen elvyttämisohjelma NOUSU. https://mmm.fi/vaelluskalat/vaelluskalaohjelma.

37 Moberg, T. \& Singler, A. 2020. Restoring Free-flowing Rivers in Europe. The Nature Conservancy. https://www.nature.org/en-us/about-us/where-we-work/europe/stories-in-europe/restoring-free-flowing-rivers-ineurope/.

38 Bergstrom, J. C. \& Loomis, J. B. 2017. Economic valuation of river restoration: An analysis of the valuation literature and its uses in decision-making. Water Resources and Economics 17: 9-19.

39 Jørgensen, D. \& Renöfält, B. M. 2013. Damned if you do, dammed if you don't: debates on dam removal in the Swedish media. Ecology and Society, 18(1).

40 Pounds, J. A., Bustamante, M. R., Coloma, L. A., Consuegra, J. A., Fogden, M. P. L., Foster, P. N., La Marca, E., Masters, K. L., Merino-Viteri, A., Puschendorf, R., Ron, S. R., Sanchez-Azofeifa, G. A., Still, C. J. \& Young, B. E. 2006: Widespread amphibian extinctions from epidemic disease driven by global warming. Nature 439: 161-167.

41 Pöyry, J. \& Aapala, K. (toim.) 2020. Lajit ja luontotyypit muuttuvassa ilmastossa. Suomen ympäristökeskuksen raportteja 2/2020: 1-207.

42 Pöyry, J., Luoto, M., Heikkinen, R.K., Kuussaari, M. \& Saarinen, K. 2009. Species traits explain recent range shifts of Finnish butterflies. Global Change Biology 15: 732-743.

43 Lehikoinen, A. \& Virkkala, R. 2016. North by north-west: climate change and directions of density shifts in birds. Global Change Biology 22: 1121-1129. 
44 Virkkala, R., Rajasärkkä, A., Heikkinen, R.K., Kuusela, S., Leikola, N. \& Pöyry, J. 2018. Birds in boreal protected areas shift northwards in the warming climate but show different rates of population decline. Biological Conservation 226: 271-279.

45 Mackenzie, B. R., Gislason, H., Mollman, C. \& Koster, F. W. 2007. Impact of 21st century climate change on the Baltic Sea fish community and fisheries. Global Change Biology 13: 1348-1367.

46 Westerbom, M. 2006. Population dynamics of blue mussels in a variable environment at the edge of their range. PhD thesis. University of Helsinki, Faculty of Biosciences, Department of Biological and Environmental Sciences.

47 Reusch, T. B., Dierking, J., Andersson, H. C., Bonsdorff, E., Carstensen, J., Casini, M., ... \& Zandersen, M. 2018. The Baltic Sea as a time machine for the future coastal ocean. Science Advances, 4(5), eaar8195.

48 IPBES. 2018. Summary for policymakers of the assessment report on land degradation and restoration of the Intergovernmental SciencePolicy Platform on Biodiversity and Ecosystem Services. R. Scholes, L. Montanarella, A. Brainich, N. Barger, B. ten Brink, M. Cantele, B. Erasmus, J. Fisher, T. Gardner, T. G. Holland, F. Kohler, J. S. Kotiaho, G. Von Maltitz, G. Nangendo, R. Pandit, J. Parrotta, M. D. Potts, S. Prince, M. Sankaran \& L Willemen (eds.). IPBES secretariat, Bonn, Germany.

49 Willemen L., Barger, N. N., Ten Brink, B., Cantele, M., Erasmus, B. F., Fisher, J. L., Gardner, T., Holland, T.G., Kohler, F., Kotiaho, J.S., ... \& Scholes, R. 2020. How to halt the global decline of lands. Nature Sustainability, 3(3), 164-166.

50 Virkkala, R., Heikkinen, R., Lehikoinen, A. \& Valkama, J. 2014. Matching trends between recent distribution changes of northern-boreal birds and species-climate model predictions. Biological Conservation 172: 124-127.

51 Virkkala, R.; Aalto, J.; Heikkinen, R.K.; Rajasärkkä, A.; Kuusela, S.; Leikola, N.; Luoto, M. 2020. Can Topographic Variation in Climate Buffer against Climate Change-Induced Population Declines in Northern Forest Birds? Diversity 2020, 12, 56. https://doi.org/10.3390/d12020056.

52 Lehikoinen, P., Santangeli, A., Jaatinen, K., Rajasärkkä, A. \& Lehikoinen, A. 2019. Protected areas act as a buffer against detrimental effects of climate change - evidence from long term abundance data. Global Change Biology 25: 304-313.

53 Lehikoinen, A., Virkkala, R. \& Väisänen, R. A. 2020. Suomen maalintujen tiheyssiirtymät. Linnut-vuosikirja 2019: 6-21.

54 Aapala, K., Akujärvi, A., Heikkinen, R.K., Pöyry, J., Virkkala, R., Aalto, J., Forss, S., Kartano, L., Kemppainen, E., Kuusela, S., Leikola, N., Mattsson, T., Mikkonen, N., Minunno, F., Piirainen, S., Punttila, P., Pykälä, J., Rajasärkkä, A., Syrjänen, K. \& Turunen, M. 2020. Suojelualueverkosto muuttuvassa ilmastossa - kohti ilmastoviisasta suojelualuesuunnittelua. Suomen ympäristökeskuksen raportteja 1/2020: 1-66.

55 Virkkala, R., Heikkinen, R.K., Kuusela, S., Leikola, N. \& Pöyry, J. 2019. Significance of protected area network in preserving biodiversity in a changing northern European climate. s. 377-390. Teoksessa Leal Filho, W., Barbir, J. \& Preziosi, R. (toim.): Handbook of climate change and biodiversity. Springer, Cham, Switzerland.

56 Heikkinen, R.K., Pöyry, J., Fronzek, S. \& Leikola, N. 2012. IImastonmuutos ja vieraslajien leviäminen Suomeen Tutkimustiedon synteesi ja suurilmastollinen vertailu. Suomen ympäristö 7/2012: 1-117.

57 Kotiaho, J. S. 2017. On effective biodiversity conservation, sustainability of bioeconomy, and honesty of the Finnish forest policy. Annales Zoologici Fennici 54: 13-25.

58 Kalliokoski, T., Bäck, J., Boy, M., Kulmala, M., Kuusinen, N., Mäkelä, A., Minkkinen, K., Minunno, F., Paasonen, P., Peltoniemi, M., Taipale, D., Valsta, L., Vanhatalo, A., Zhou, L., Zhou, P. \& Berninger, F. 2020. Mitigation impact of different harvest scenarios of Finnish forests that account for albedo, aerosols and trade-offs of carbon sequestration and avoided emissions. Front. For. Glob. Change. doi: 10.3389/ffgc.2020.562044.

59 Soimakallio, S. , Saikku, L., Valsta, L. T. \& Pingoud, K. 2016. Climate change mitigation challenge for wood utilization the case of Finland. Environmental science \& technology 50(10): 5127-5134 . doi: 10.1021/acs.est.6b00122.

60 Lankia, T., Kopperoinen, L., Pouta, E., \& Neuvonen, M. 2015. Valuing recreational ecosystem service flow in Finland. Journal of outdoor recreation and tourism 10: 14-28.

61 Puustinen, J., Pouta, E., Neuvonen, M. \& Sievänen, T. 2009. Visits to national parks and the provision of natural and man-made recreation and tourism resources. Journal of Ecotourism 8(1): 18-31.

62 Mann, C., Pouta, E., Gentin, S. \& Jensen, F. S. 2010. Outdoor recreation in forest policy and legislation: A European comparison. Urban forestry \& urban greening 9(4): 303-312.

63 McLean, S. 2013. The whiteness of green: Racialization and environmental education. The Canadian Geographer/Le Géographe Canadien 57(3): 354-362. 
64 Wood, B. \& Kallio, K.P. 2019 Green citizenship: towards spatial and lived perspectives. Teoksessa Davoudi, S., Blanco, H., Cowell, R. and White, I. (toim.) Routledge Companion to Environmental Planning and Sustainability, 171-180. London: Routledge.

65 Aarnio-Linnanvuori, E. I. 2016. Ympäristöaiheiden tieteidenvälisyys yleissivistävän opetuksen haasteena aineenopettajien näkökulmasta. Kasvatus \& Aika 10(2): 33-50.

66 Kortetmäki, T. 2018. Ruokaoikeudenmukaisuus ja ympäristökysymys. Alue ja Ympäristö 47(2): 3-16.

67 Häkli, J., Kallio, K.P. \& Ruokolainen, O. 2020. A missing citizen? Issue-based citizenship in city-regional planning. International Journal of Urban and Regional Research 44:5 876-893.

68 Opetus- ja kulttuuriministeriön julkaisuja. 2020. Opetus- ja kulttuuriministeriön hallinnonalan kestävän kehityksen linjaus http://urn.fi/URN:ISBN:978-952-263-704-8.

69 Baruch, Z., Liddicoat, C., Cando-Dumancela, C., Laws, M., Morelli, H., Weinstein, P., ... \& Breed, M. F. 2020. Increased plant species richness associates with greater soil bacterial diversity in urban green spaces. Environmental Research, 110425.

70 Selway, C. A., Mills, J. G., Weinstein, P., Skelly, C., Yadav, S., Lowe, A., ... \& Weyrich, L. S. 2020. Transfer of environmental microbes to the skin and respiratory tract of humans after urban green space exposure. Environment International, 145, 106084.

71 Roslund, M., Puhakka, R., Grönroos, M., Nurminen, N., Oikarinen, S., Gazali, A.M., Cinek, O., Kramná, L., Siter, N., Vari, H.J., Soininen, L., Parajuli, A., Rajaniemi, J., Kinnunen, T., Laitinen, O.H., Hyöty, H., Sinkkonen, A. 2020. Biodiversity intervention enhances immune regulation and health-associated commensal microbiota among daycare children. Science Advances 6 (42): eaba2578. doi: 10.1126/sciadv.aba2578.

72 Haahtela, T., Holgate, S., Pawankar, R., Akdis, C. A., Benjaponpitak, S., Caraballo, L., ... \& Von Hertzen, L. 2013. The biodiversity hypothesis and allergic disease: world allergy organization position statement. World Allergy Organization Journal 6(1): 1-18.

73 Koskela, S., Korhonen, M-R., Seppälä, J., Häkkinen, T. ja Vares, S. 2011. Materiaalinäkökulma rakennusten ympäristöarvioinnissa. Suomen ympäristökeskuksen raportteja 16/2011.

74 Antikainen, R., Dalhammar, C., Hildén, M., Judl, J., Jääskeläinen, T., Kautto, P., Koskela, S., Kuisma, M., Lazarevic, D., Mäenpää, I., Ovaska, J.-P., Peck, P., Rodhe, H., Temmes, A., Thidell, Å. 2017. Renewal of forest based manufacturing towards a sustainable circular bioeconomy. Reports of the Finnish Environment Institute 13/2017.

75 McCay, A. T., Feliks, M. E. \& Roberts, J. J. 2019. Life cycle assessment of the carbon intensity of deep geothermal heat systems: A case study from Scotland. Science of the Total Environment 685: 208-219.

76 Oksanen E, Kontunen-Soppela S. 2021. Plants have different strategies to defend against air pollutants. Current Opinion in Environmental Science \& Health 19:100222. doi: 10.1016/j.coesh.2020.10.010.

77 Yeung LY, Murray LT, Martinerie P, et al. 2019. Isotopic constraint on the twentieth-century increase in tropospheric ozone. Nature 570:224-227.

78 Agathokleus, E., Zhaozhong, F., Oksanen, E., Sicard, P., Wang, Q., Satanis, C.J., Araminiene, V., Blande, J.D., Hayes, F., Calatayud, V,. Domingos, M., Veresoglou, S.D., Penuelas, J., Wardle, D.A., De Marco, A., Li, Z., Harmens, H., Yuan, X., Vitale, M., Paoletti, E. 2020. Ozone affects plant, insect and soil microbial communities: A threat to terrestrial ecosystems and biodiversity. Science Advances 6, no. 33 eabc1176. doi: 10.1126/sciadv.abc1176.

79 Imperato, V. et al. 2019. Characterisation of the Carpinus betulus L. phyllomicrobiome in urban and forest areas. Front Microbiol 10: 1110; IPCC, Climate Change and Land, Report 2019. https://www.ipcc.ch/site/assets/uploads/2019/08/2c.Chapter-2 FINAL.pdf.

80 Vacher C et al. 2016. The hyllosphere: microbial jungle at the plant-climate interface. Annu Rev Ecol Evol System 47:1.

81 Vanderkoornhuyse, P. et al. 2015. The importance of the microbiome of the plant holobiont. New Phytol 206:119.

82 Wang, Y., Jin, W., Che, Y., Huang, D., Wang, J., Zhao, M., Sun, G. 2019. Atmospheric nitrogen dioxide improves photosynthesis in mulberry leaves via effective utilization of excess absorbed light energy. Forests 10:312.

83 Oh, K., Thi, L.T., Jeong, B.R. 2019. Particulate matter in the cultivation area may contaminate leafy vegetables with heavy metals above safe levels in Korea. Environ Sci Pollut Res 26: 25762-25774. 
84 Dirnböck, T., Grandin, U., Bernhardt-Römermann, M., Beudert, B., Canullo, R., Forsius, M., ... Uziębło, A. K. 2014. Forest floor vegetation response to nitrogen deposition in Europe. Global Change Biology 20(2): 429-440. doi:10.1111/gcb.12440.

85 Pöyry, J., Carvalheiro, L. G., Heikkinen, R. K., Kühn, I., Kuussaari, M., Schweiger, O., . . F Franzén, M. 2017. The effects of soil eutrophication propagate to higher trophic levels. Global Ecology and Biogeography 26(1): 18-30. doi:10.1111/geb.12521.

86 Chen, Y., Ebenstein, A., Greenstone, M. \& Li, H. 2013. Evidence on the impact of sustained exposure to air pollution on life expectancy from China's Huai River policy. Proceedings of the National Academy of Sciences 110(32): 12936-12941.

87 Greenstone, M. \& Hanna, R. 2014. Environmental regulations, air and water pollution, and infant mortality in India. American Economic Review 104(10): 3038-72.

88 Duflo, E., Greenstone, M., \& Hanna, R. 2008. Indoor air pollution, health and economic well-being. SAPI EN. S. Surveys and Perspectives Integrating Environment and Society (1.1).

89 Immerzeel, D. J., Verweij, R. A., Van Der Hilst, F., Faaij, A. P. C. 2014. Biodiversity impacts of bioenergy crop production: a state-of-the-art review. GCB Bioenergy 6:183-209. doi: 10.1111/gcbb.12067.

90 Framstad E., Berglund, H., Gundersen, V., Heikkilä, R., Lankinen, N., Peltola, T., Risbøl, O. \& Weih, M., 2009. Increased biomass harvesting for bioenergy: effects on biodiversity, landscape amenities and cultural heritage values. Nordic Council of Ministers.

91 Popp, D., Von Gillhaussen, P., Weidlich, E. W. A., Sträuber, H., Harms, H., Temperton, V. M. 2017. Methane yield of biomass from extensive grassland is affected by compositional changes induced by order of arrival. GCB Bioenergy 9 : 1555-1562. doi: 10.1111/gcbb.12441.

92 Luostarinen, S., Tampio, E., Niskanen, O., Koikkalainen, K., Kauppila, J., Valve, H., ... \& Ylivainio, K. 2019. Lantabiokaasutuen toteuttamisvaihtoehdot.

93 MarMoni. 2016. Guidelines for environmental impact studies on marine biodiversity for offshore windfarm projects in the Baltic Sea Region.

94 Virtanen, E. A., Viitasalo, M., Lappalainen, J., \& Moilanen, A. 2018. Evaluation, gap analysis, and potential expansion of the Finnish marine protected area network. Frontiers in Marine Science 5(402).

95 Lukkarinen, J., Marttila, T., Saarikoski, H., Auvinen, K., Faehnle, M., Hyysalo, S., Kangas, H.-L., Lähteenoja, S., Peltonen, L. \& Salo, M. 2020. Taloyhtiöistä tulevaisuuden energiatuottajia - Muutospolut vuoteen 2035 ja murrosareena tiedon yhteistuotannon menetelmänä. Suomen ympäristökeskuksen raportteja 39/2020.

96 Kontula, T. \& Raunio, A. 2018. Suomen luontotyyppien uhanalaisuus 2018: Luontotyyppien punainen kirja. Osa 1: Tulokset ja arvioinnin perusteet.

97 HELCOM. 2018. HELCOM Thematic assessment of eutrophication 2011-2016. Baltic Sea Environment Proceedings No. 156.

98 HELCOM. 2021. HELCOM Hot Spots. https://helcom.fi/action-areas/industrial-municipal-releases/helcom-hot-spots/.

99 Ahlvik, L. \& Hyytiäinen, K. 2015. Value of adaptation in water protection-Economic impacts of uncertain climate change in the Baltic Sea. Ecological Economics 116: 231-240.

100 Andersson, A., Meier, H. M., Ripszam, M., Rowe, O., Wikner, J., Haglund, P., ... \& Elmgren, R. 2015. Projected future climate change and Baltic Sea ecosystem management. Ambio 44(3): 345-356.

101 Neumann, T., Eilola, K., Gustafsson, B., Müller-Karulis, B., Kuznetsov, I., Meier, H. M. \& Savchuk, O. P. 2012. Extremes of temperature, oxygen and blooms in the Baltic Sea in a changing climate. Ambio 41(6): 574-585. 
Suomen Luontopaneelin julkaisuja 1/2021

Kannanotto

\section{Luonnon monimuotoisuus ja vihreä elvytys}

Tekijät:

Lassi Ahlvik (Helsingin yliopisto, lassi.ahlvik@helsinki.fi), Christoffer Boström (Åbo Akademi), Jaana Bäck (Helsingin yliopisto), Irina Herzon (Helsingin yliopisto), Jukka Jokimäki (Arktinen keskus), Kirsi Pauliina Kallio (Tampereen yliopisto), Tarmo Ketola (Jyväskylän yliopisto), Liisa Kulmala (Ilmatieteen laitos), Aleksi Lehikoinen (Luonnontieteellinen keskusmuseo Luomus), Tiina M. Nieminen (Luonnonvarakeskus), Elina Oksanen (Itä-Suomen yliopisto), Minna Pappila (Turun yliopisto), Juha Pöyry (Suomen ympäristökeskus), Heli Saarikoski (Suomen ympäristökeskus), Aki Sinkkonen (Luonnonvarakeskus), Ilari Sääksjärvi (Turun yliopisto) ja Janne S. Kotiaho (Jyväskylän yliopisto)

Toimitussihteeri: Sanna Autere

ISSN: 2737-0062

\section{DOI: https://doi.org/10.17011/jyx/SLJ/2021/1}

Viittausohje:

Suomen Luontopaneeli. 2021. Luonnon monimuotoisuus ja vihreä elvytys. Suomen Luontopaneelin julkaisuja 1/2021.

Suomen Luontopaneeli on riippumaton asiantuntijaelin, joka tukee luontopolitiikan suunnittelua ja päätöksentekoa. Luontopaneelin kannanotot ja raportit perustuvat tieteelliseen näyttöön ja monialaiseen asiantuntemukseen.

\section{www.luontopaneeli.fi}

@luontopaneeli 